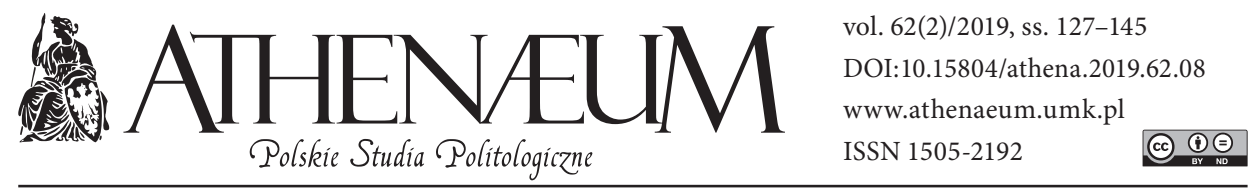

\title{
GLOBALIZM: WIZJE I PROJEKTY PAŃSTWA GLOBALNEGO
}

\author{
GLOBALISM: VISIONS AND PROJECTS OF GLOBAL STATE
}

Andrzej Sepkowski*

\begin{abstract}
ABSTRAKT
Coraz intensywniejsze powiązania między państwami i ludźmi, lepiej znane jako globalizacja, są dziś przesłankami do sądów o konieczności wykreowania rządów i form zarządzania na poziomie globalnym. Zgadzający się na taki ogląd utrzymują, że tylko poprzez rząd globalny / dla autora jest to globalizm / państwa i narody będą mogły kooperować na wielu polach od ekonomicznej poczynając, a politycznej i bezpieczeństwa kończąc, prowadząc dialog w sposób pokojowy, bezkonfliktowy. Brak zarządzania globalnego owocuje barierami, protekcjonizmem i warunkami sprzyjającymi konfliktom. Idea globalnego państwa jest zamysłem wprowadzenia tego, co najlepsze, w społeczność międzynarodową i uratowania jej od form zła spotykanych dziś.

Zauważamy, iż globalizm ma pociągać za sobą systematyczną transformację organizacji politycznej i ekonomicznej państw umocowanych w suwerenności terytorialnej w kierunku wciąż niejasnych kształtów nieterytorialnych, nadnarodowych struktur rządzenia. Obecnie
\end{abstract}

The intensifying connections between states and peoples, better known as globalization, are now frequently presumed to create the need for governance and rule-making at the global level. According to such a view, only with global governance (for the author it is globalism) will states and peoples be able to cooperate on economic, environmental, security and political issues, settle their disputes in a nonviolent manner and advance their common interests and values. Absent of global government, states are likely to retreat behind protective barriers and re-create the conditions for enduring conflict. Global governance is thought to bring out the best in the international community and rescue it from its worst instincts.

As we see, globalization entails a systemic transformation of the organization of politics and economics from the modern state system grounded in sovereign territoriality to a still unclear mode of organization that will entail non-territorial, transnational governance structures. It is a period characterized by "gover-

* Uniwersytet Łódzki, Wydział Studiów Międzynarodowych i Politologicznych. 
żyjemy w okresie charakteryzowanym jako „rządzenie bez rządu”. Chociaż wiele międzynarodowych instytucji jest reprezentowanych przez demokratycznie wybierane rządy, to te fakty ani są dobrze zrozumiałe, ani transparentne. Ch. Kindleberger, historyk ekonomii, powiedzial pewnego razu, że państwa narodowe mogą sobie radzić politycznie, ale są zbyt małe, by znaczyć wiele kulturowo. Oczywiście jasne jest, że istniejące już instytucje niewiele znaczą dla większości ludzi i brak im politycznej legitymacji, chociaż wiele $\mathrm{z}$ wciąż potężniejących problemów może być rozwiązanych tylko przez współpracę międzynarodową. Zadanie łagodzenia negatywnych konsekwencji globalizacji poprzez struktury zarządzania globalnego może powiększyć zasięg potrzeb i przesłanek do efektywnej współpracy.

Słowa kluczowe: wizje świata jutra; ład międzynarodowy; globalizm; globalizacja; państwo globalne nance without government". Although many of international institutions are representatives of democratically elected governments, this fact is not well understood and often not transparent. Charles Kindleberger, the economic historian, once said that nation states may be about the right size politically but are too small to be meaningful culturally. Yet, it is clear that existing institutions of global governance are not yet meaningful to most people and lack political legitimacy, although a large and growing number of significant problems can only be dealt with internationally. The task is to resolve the negative consequences of globalization through a governance structure responsive to a wide range of needs and concerns and consistent with effective participatory.

Keywords: visions of tomorrow's world; international order; globalism; globalization; global state

W poniższych rozważaniach chcemy skupić się na ożywającym dyskursie na temat nowego ładu globalnego, z braku miejsca traktując bardzo pobieżnie antecedencje globalizmu, których jest więcej niż sądzimy i które wypływają z różnych, czasami dziwnych źródeł, choć wielu autorów poszukuje ich w utopii, przy czym interpretacje tej metafory bywają niekiedy bardzo swobodne. Przywołanie ich zdaje się potrzebne dla podkreślenia żywotności, dynamiki i wpływu na wyobrażenia zbiorowe w naszym czasie. Różnorakie wizje i projekcje, bo nie konkretne projekty global governance czy global government, które są postaciami globalizmu, bardzo swobodnie interpretowanymi przez zajmujących się globalizacją, pojawiają się w pracach naukowych, publicystyce, będąc nader często ozdobnikami, acz szeroko dyskutowanymi w kręgach liberalnych idealistów, zwolenników koncepcji świata bez państw narodowych, różnic rasowych i kulturowych, niebiorących pod uwagę realiów naszego skomplikowanego świata, zwykle chcących mierzyć go swoimi miarami. Z wielu względów niełatwo je zrozumieć i wyjaśnić, ale takie zbliżenie jak poniższe zdaje się potrzebne po to, by móc potraktować takie wizje jako część „ideologii nowego świata”.

Wydawać się może, że te wizje są dziś tworzone na zasadzie „więcej tego samego" i ich autorzy, należący do takiego samego grona wyznawców, nawet nie 
próbują zadawać niezbędnych pytań badawczych, poszukiwać determinantów zmian, uznając swoje racje za ostateczne, za efekty swoistej iluminacji. Tak prezentują się choćby przeciwstawne mity dobrej i złej globalizacji w interpretacji J.E. Stiglitza i J. Norberga. W ich przypadku nauka znajduje się zbyt blisko wiatry immanentnej. J. Gray, podkreślając siłę takiej wiary, zauważył, że od początku lat 80. przekonanie, iż jeden system polityczny i ekonomiczny zapanuje na całym świecie, zaczęło kształtować polityką państw zachodnich (2009). Potwierdzeniem takich oczekiwań jest choćby bezkrytyczne przyjęcie przez środowiska naukowe prac F. Fukuyamy.

Poniższe uwagi, próby zrozumienia i genetycznego wyjaśnienia istoty globalizmu są owocem wieloletniego zainteresowania autora wizjami, projektami i planami przyszłości, czego potwierdzeniem są liczne publikacje. Poruszanie się w prawdziwym gąszczu reprezentatywnych koncepcji „teorii”, mających bardzo dużą literaturę, było jednak trudne w tak ograniczonych ramach, zmuszało do symplifikacji, pomijania wielu wątków, zagadnień, a to zwykle nie satysfakcjonuje samego autora.

Archetyp państwa globalnego, uniwersalnej, pokojowej i szczęśliwej państwowości, sięga pradziejów człowieka, a jego ślady dostrzeżemy nie tylko w Starym Testamencie i micie sięgającej nieba wieży budowanej na rozkaz króla Nemroda, lecz także w kulturach dalekich od siebie. Jest wyrazem ludzkich tęsknot za ideałem i takim zapewne pozostanie bez względu na to, co nas czeka. A nowe idee - zauważał G. Lakoff - nigdy nie są całkiem nowe. Muszą korzystać z idei już obecnych w ludzkiej kulturze, obumierających i ożywających na nowo w kole wiecznego powrotu (2017). Rodziła go utopia - wieczna hipostaza ludzkich złudzeń i trwał przez wieki w dwóch postaciach kultywowanych przez inne grupy ludzkie: kapłanów - wyznawców świeckiej soteriologii i zdobywców, tak często niepotrafiących znaleźć granic swych ambicji.

Z jednej strony były to marzenia polityków, ludzi władzy, chcących stworzyć ziemską ekumenę przez podbój i narzucenie innym swoich praw uważanych przez nich i dla nich za najlepsze, a z drugiej intelektualistów, ludzi wiedzy (często gnostyków), wierzących w dobro i piękno natury ludzkiej, ludzi myśli od wieków uważających, iż stworzenie wspólnoty ludzkiej jest wymogiem swoiście rozumianej racjonalności przy założeniu dobrej woli ludzi władzy. Byli i pozostają swoiście „utopijni” ze swoimi marzeniami o ziszczonym ideale, o niebie na ziemi, nie chcą zauważać, że dziś ostatnią rzeczą, jakiej potrzebujemy - konstatował trzeźwo I. Wallerstein - jest więcej utopijnych wizji (2006). Zauważał, iż w imię dobra wszystkich ludzi utopijni wizjonerzy wieku XX sprowadzili na świat 
ogrom nieszczęść, o jakich nigdy nie zapomnimy i współtworzyli „spustoszone stulecie”, co przypomina się zbyt rzadko, po części za sprawą ich sukcesorów, którzy nie chcą przyznawać się do korzeni, a skutecznie sprawują role władców symboli w wielu krajach. Komentując dwie postaci wizji, D. Korten zauważał, że idee imperium i ziemskiej wspólnoty płyną z innych źródeł. Wspólnota oparta na najszlachetniejszych ideałach ludzkości to wybór i odpowiedzialność za wspólne dobro. Imperium natomiast to gwałt, wykluczenie, dominacja mniejszości (2006). Dla niego depozytariuszami pierwszej są ludzie myśli, drugiej ludzie władzy, co nie zawsze oznacza polityków.

Wokół tego zjawiska pojawiło się sporo nieporozumień, zwykle biorących się z prostego utożsamienia $\mathrm{z}$ globalizacją polityczną, a nawet $\mathrm{z}$ imperializmem amerykańskim, co dla autora jest trudne do zrozumienia, gdy spotyka takie rażące uproszczenia w podręczniku akademickim, mającym kilkanaście wydań tylko do roku 1997 (Ambrose, Brinkley, 1997). Taki podręcznik, pełen uproszczeń, kraszony obficie „amerykańską ideologią”, może znakomicie służyć zamykaniu młodych umysłów w rozumieniu A. Blooma (1997), ale nie zrozumieniu.

Dla autora globalizm to zdecydowanie wizje zunifikowanej politycznie, kulturowo społeczności ziemskiej, zwykle bez telosów, bo taka jest natura wizji, zbyt często traktowanych jak metafory. A one są „,horyzontem nowych dążeń, pełnego miejsc, których nigdy jeszcze nie oglądało ludzkie oko" - pisał wizyjny G. Therborn, trafnie oddający ich naturę (1998). Nim wielkie wizje społeczności ziemskiej zorganizowanej w państwie globalnym owładnęły wyobrażeniami dużych grup społecznych za pośrednictwem ludzi myśli, pojawiły się próby tworzenia takiej jakości przez siłę, nazywaną typem dominatorskim albo imperialnym. Nie wspominając uprzednich prób dokonywanych przez Sumerów, Egipcjan, Asyryjczyków czy Greków, zauważmy tylko, że jedną z wielu nieudanych prób było imperium rzymskie z ładzącą wiekowe podboje ideą pax Romana. Później sukcesorów takiej formy globalizmu było wielu i poprzez okres karoliński, pax Christiana, dotrzeć możemy do XX wieku - wieku uniwersalizmu w obu postaciach.

Marzenia o zdominowaniu świata towarzyszyły Hitlerowi i Stalinowi, a ich źródła, zdaniem jednego z autorów, kryły się w mrokach średniowiecza i dla niego hitlerowskie tysiącletnie państwo wywodzi się ze spekulacji Joachima z Fiore, co zdaje się swoistą nadinterpretacją albo właśnie spekulacją (Voegelin, 1992). Zbyt często gubimy się w poszukiwaniach źródeł zjawisk, procesów i niekiedy niewielkie nawet podobieństwa służą nam jako przesłanki do zbyt pochopnych wniosków. Równie zasadnie bowiem można by się odwoływać choćby do idei millenarystycznych. 
Takie marzenia kratycznych - jak ci dwaj - polityków zdają się już przeszłością, choć wiemy, że przyszłość jest nieprzewidywalna i mogą pojawić się jednostki dysponujące mocą zmieniania świata z własnymi wizjami, wierzących w samosprawdzające się, tworzone przez nich samych „prognozy”. W naszym czasie jednak dominują już wizje pokojowej unifikacji i apogeum takich dysput przypada właśnie na pierwszą dekadę XXI stulecia, co zdaje się być konsekwencją dalszych postępów globalizacji, umacniania się struktur „trzeciej fali” z ich kulturową emanacją, czyli postmodernizmem. Ich zbliżenie warto jednak poprzedzić kilkoma uwagami o projektach wcześniejszych, by zasygnalizować niezwykłą żywotność globalizmu, a ze względów sentymentalnych wypada zacząć od polskich wizji autorstwa Z. Świętosławskiego.

Jeden z przywódców Gromad Ludu Polskiego w drugiej fazie ich istnienia okazał się być rewelatorem największych prawd o przeznaczeniu świata, tworząc „Ustawy Kościoła Powszechnego”. Ewangeliczne, starannie stylizowane „Ustawy” są swoistym dekalogiem obowiązków całej ludzkości, przy niemal całkowitym braku praw jednostek i grup, co czyniło je bliskimi dystopii. Projektują dla niej jedno, niepodzielne państwo globalne, państwo nowego Kościoła, którego jedyną i wystarczającą legitymacją jest Bóg chrześcijan i jego prawa interpretowane przez rewelatora. Dziećmi tego Kościoła są wszyscy ludzie zamieszkujący kulę ziemską, a poza nim nie ma zbawienia w niebie. Jego Kościół, zdecydowanie wrogi rzymskiemu, miał być jedynym, inne zaś „nie miały być cierpiane”, co oznaczało ich eliminację przez przemoc. O niepodzielności charakteru całej ludzkości miała stanowić wspólnota wiary, bynajmniej nie dobrowolna. Bezkompromisowy twórca „Ustaw” widział ją jako wspólnotę organiczną, a podział na narody miał pozostać tylko podziałem administracyjnym. Jedynym, czysto polskim akcentem miał być obowiązujący język polski, „najdoskonalszy dla oddawania myśli, uczuć i pojęć wieków przyszłych" (1854).

Ten projekt ładu nie został zauważony poza ewazyjną wspólnotą, ale dokonania socjalistów przełomu wieków, zwłaszcza E. Bellamy, już wzbudziły gorące dyskusje, co poświadcza wielu polskich intelektualistów z B. Prusem na czele. Jego powieści $W$ roku 2000 i Equality fascynowały intelektualne, socjalistyczne środowiska przez lata, inspirowały następców, takich jak I. Donnely, Th. Hertzka i wydaje się, że miały spory wpływ na polityków marzących o wielkim państwie globalnym, zwłaszcza w nieodmiennie misyjnych Stanach Zjednoczonych. Nie tylko na polityków, bowiem w sukurs tworzącym ze współczynnikiem licentia poetica poszły autorytety tego czasu z H.G. Wellsem na czele, dla którego rząd światowy, pokój i uniwersalna religia, której kształtu nie precyzował, są prze- 
znaczeniem świata, zdeterminowanym przez siły nieubłaganego postępu (Sobel, 1993).W fikcyjnej historii przyszłości, wydanej w 1933 roku, Wells przewidywał długotrwałą wojnę światową zakończoną ukonstytuowaniem państwa globalnego, powstałego za sprawą ludzi nauki, którzy wynaleźli super broń i szantażując nią wszystkich, wymusili powstanie tego typu państwa.

W początkach wieku idee państwa globalnego nader poważnie traktowali misyjni Amerykanie, którzy myśleli o zainicjowaniu budowy społeczeństwa globalnego. Dał temu wyraz wpływowy W. Lippman, pisząc na łamach New Republic w 1917 roku: „Wielka nadzieja świata to nic więcej jak Federacja Światowa" (Kennedy, 1982). Podzielał takie zdanie misyjny prezydent Woodrow Wilson, jeden z inicjatorów powstania Ligi do Wymuszania Pokoju (Ligi Tafta). Nie był oryginalny, twierdząc, że wartości narodowe Ameryki były identyczne $z$ uniwersalnymi, a ta wyjątkowa Ameryka powinna prowadzić ludzkość do uniwersalnego społeczeństwa przyszłości, bo tylko ona jest do tego predestynowana. Dzielił nadzieję, że Liga Narodów będzie wstępem do tworzenia rządu światowego (Gordon Levin Jr., 1970). Zawiódł się bardzo postawami Europejczyków, bo amerykańska krucjata w próbie odnowienia Starego Świata skończyła się ostatecznie po rezygnacji z uczestnictwa w pracach Ligi Narodów.

Po II wojnie na czas jakiś ożyły obawy o próby zdominowania przestrzeni globalnej przez jedno mocarstwo. Przez cały okres zimnej wojny takie obawy wyrażali i Amerykanie i Rosjanie, acz na inne sposoby. Amerykanie częściej obawiali się otwartej agresji i nawet okupacji Stanów, Rosjanie zaś, podkreślając pokojowe zamiary, wykazywali niezwykłą pewność co do wyższości systemu komunistycznego i jego przyszłości. Czołowy ideolog KPZR, jeszcze w końcu lat 70. uważał, że: „Wiek XXI nieuchronnie przyniesie dalszy rozwój cywilizacji komunistycznej (Szachnazarow, 1978). I w naszym czasie pozostałości tej „cywilizacji” dają znać o sobie w zachowaniach i postawach wielu „liberalnych” intelektualistów, czego nie chcemy zauważać, bo: „żyjemy pośród ruin ery nowożytnej, a one zasłaniają nam świat" (Gray, 2001). W naszym czasie - zauważał L. Zacher - gdy przez świat przetaczają się dwie albo trzy fale przemian, to żadna z nich nie dominuje wyraźnie, a obraz świata jest nieostry (2006). W takiej sytuacji zagubienia zwykle potrzebujemy nie mądrości, a pewności, i to bywa przyczyną wielu błędów już nie do naprawienia.

Lata 70., pełne pozorowanych porozumień dwu i wielostronnych, znów pobudziły optymizm intelektualistów spod znaku Klubu Rzymskiego i World Order Model Project, wykazujących pichtowską odwagę utopii wobec problemów poszerzającego się świata. Przesiąknięte pozornym altruizmem, pełne 
nieuprawnionych wniosków pierwsze Raporty dla Klubu przypominające prowokacje, tworzyły wyzwania dla pierwszego świata, przy czym politycy nie traktowali ich poważnie w dobie kiełkującej globalizacji, kiedy M. Mesarovic, E. Pestel czy J. Tinbergen postulowali współpracę międzynarodową jako jedyne wyjście dla świata, nie próbując określać form takiej współpracy; nie wiadomo było również, czemu te Raporty miały służyć. Były po trosze imperatywami, po trosze katalogami pobożnych życzeń, mimo iż można w nich odnaleźć wiele antycypacji dzisiejszych zagrożeń, w tym konfliktu między Północą a Południem, konfliktu wielopłaszczyznowego, którego konsekwencją będzie wielka wędrówka ludów, taka, jaka staje się naszą rzeczywistością. Takie próby przewidywania, oparte na zauważalnych megatrendach, nie były zbyt trudne.

Nawoływania do solidarnego współdziałania płynące z Klubu nie skończyły się w latach 70. W Raporcie A. Kinga i B. Schneidera także znajdziemy gorące nawoływania kierowane do wszystkich: „Możemy szerzyć na całym świecie ideę rozumnego, wspólnego zainteresowania przetrwaniem rodzaju ludzkiego i ludzkich społeczeństw" (1992). Podobnie prezentowały się apele Światowych Federalistów, nawołujące w latach 70. do jak najszybszego tworzenia państwa globalnego. Takie nawoływania były po części reakcją na pogłębiający się chaos polityczny w krajach Trzeciego Świata, załamywanie ładu globalnego w czasie krzepnięcia, poszukiwania tożsamości przez nowe podmioty na arenie międzynarodowej.

Nieco inaczej zaś wyglądały prace autorów powiązanych z WOMP.R. Kothari postawił szereg pytań o konkretne warunki, jakie winny towarzyszyć powstawaniu zaczynów rządu globalnego. Były to dosyć konkretne pytania o model instytucjonalny, formy organizacji terytorialnej, czy składowe federacji światowej (Kothari, 1978). Pytania jednak zasadne wobec wizjonerów niezbyt odpowiedzialnych za słowo. Odpowiedzi już nie mogły satysfakcjonować, bo wedle Kothariego warto zastanowić się nad zmienioną formułą ONZ, która wedle niego się sprawdziła, ale tego zdania nie podzielali sceptycy tacy jak P. Falk, przez dziesiątki lat inicjujący dysputy nad kształtami rządu światowego. W latach 70. proponował on stworzenie Komitetu do Spraw Bezpieczeństwa Światowego ze Światowymi Siłami Bezpieczeństwa jako zaczątkiem armii rządu globalnego, Światowej Służby Rozbrojeniowej i Trybunału Światowego, rozsądzającego sprawy łamania praw narodów i państw (1975). Dalej Falk szedł śladami innych autorów Raportów dla Klubu Rzymskiego. Nie poprzestając na tworzeniu nowych rozwiązań, niebaczny na to, że jest to głos na puszczy, wespół z A. Straussem, już w naszym wieku zaproponował powołanie parlamentu światowego (Zweifel, 2006). 
Takie propozycje zdawały się typowe dla ówczesnego optymizmu grup intelektualistów, będącego w jakiejś mierze konsekwencją fetyszyzacji idei oświecenia i oświeceniowych postaci utopizmu (Acemioglu, 2014), wiary w nieograniczony postęp ludzi szeroko rozumianego Zachodu, którzy jeszcze nie odczuli skutków wielorako rozumianej globalizacji w latach 70. i 80., ani nie spotkali się z falami migracji z Południa. Pozostawali społeczeństwami wiary w stabilność systemów politycznych, gospodarczych, demokrację, taką demokrację, jaka pozostaje $\mathrm{w}$ jawnej sprzeczności z kapitalizmem. Co do tego nie mają złudzeń Hardt i Negri, powiadając, że „w naszej epoce uzbrojonej globalizacji marzenie o demokracji jest tylko ułudą" (2004).

Ludzie Zachodu schyłku tysiąclecia nie odczuli jeszcze skutków postkapitalizmu, nie rozumiejąc zbyt dobrze jego istoty. Ton naturalne, że analitycy ze środowisk naukowych są zwykle spóźnieni ze swoimi diagnozami o lata, z prognozami o dziesiątki lat, a w tym przypadku pozostawali bezradni, tworząc wiele mitów obudowujących ideologię współczesnego kapitalizmu, usprawiedliwiającą jego wilcze formy, nowe postaci kryzysów. A już niemal dwadzieścia lat wcześniej jeden $\mathrm{z}$ autorów twierdził, że można było zauważyć, jak giganty pożerają mały biznes i mityzowaną klasę średnią, rzekomą ostoję kapitalizmu (Glaasbek, 2002), że bogatsi stają się coraz bogatsi, a biedni mają więcej dzieci i czas na nowo dokonać rachunków z teraźniejszością. Takie głosy były odosobnione, zachwycano się tym, co „małe i piękne”, podkreślano, że znajdujemy się w wyjątkowym momencie historii, a wolny rynek jest panaceum na wszystkie bolączki współczesności i ostatnim stadium rozwoju formy doskonałej, jaką jest wieczny kapitalizm. Mocno podkreślano mit wzrostu gospodarczego, który praktycznie nie odzwierciedla wzrostu bądź spadku dobrobytu państwa (Korten 2001). Raczej nie słyszano głosów rozsądku, które mówiły o nowej fali bezwzględnego kapitalizmu, nowej „superklasie” ludzi dysponujących nieograniczonymi możliwościami przekształcania ładu globalnego we własnym interesie, a nawet wedle swoich kaprysów.

Wielkie korporacje finansowe i przemysłowe, dysponujące prawie nieograniczonymi możliwościami, zmieniają architekturę świata, a celem nadrzędnym zdaje się maksymalizacja zysku w bezwzględnej rywalizacji. Tworzą się nowe sieci interakcji i za ich sprawą świat się zmienił, zmienia i już nie będzie takim, jakim był. Globalny rynek kapitałowy, co nietrudno było zauważyć już kilka dekad temu, reprezentował siłę zdolną do wpływania nie tylko na politykę ekonomiczną jakiegoś państwa, ale także na inne wymiary polityki, w tym kulturowej, znaczącej więcej niż się sądzi. Nietrudno zauważyć, że postkapitalizm, czyli 
ponowoczesność, tworzy swoją emanację kulturową, jaką jest postmodernizm, i że jest ona kreowana dla potrzeb tych, którzy dysponują kapitałem i mają wiele możliwości sprawowania władzy symbolicznej albo wpływu na nią.

$\mathrm{Na}$ horyzoncie, poza silnymi państwami narodowymi, jeszcze nie ma sił zdolnych do moderowania procesów globalizacji jako takiej, a z pewnością nie są nimi prekariusze, reklamowani przez G. Standinga jako nowa, niebezpieczna dla establishmentu siła, nowy proletariat. Oni są raczej niebezpieczni dla samych siebie i tu zgadzamy się ze zdaniem T. Judda i jego analizą młodych ludzi w służbie korporacji: „Nieokreślona przyszłość bez celów i brak więzi z przeszłością upodabniają młodzież do człowieka pierwotnego - nagiego duchowo, izolowanego" (2016). Może być jeszcze gorzej, bo o jutrze będą decydować pokolenia millenialsów, X i śnieżynek / snowflakes /, skupione tylko na sobie, aspołeczne, apolityczne, zasiedziałe, zewnątrzsterowne.

W takim miejscu wypada zadać pytanie, dlaczego właśnie dziś mamy do czynienia z takim ogromem wizji, „koncepcji” światowego ładu. Wydawać się może, że wymusza je globalizacja polityczna, rosnąca liczba ubezwłasnowolnionych podmiotów państwowych i rosnąca siła korporacji poszukujących nowych ram dla działalności w sferze globalnej. Swego czasu noblista zauważał, że: „Era państwowej regulacji gospodarczej przeżyła się, era globalnej zaś jeszcze nie nadeszła" (Thurow, 1999). Taki komentarz byłby bardziej godny uwagi, gdyby Thurow wskazał symptomy nadchodzenia regulacji globalnej, bo na razie dominacja państw narodowych w sferze gospodarczej jeszcze się umacnia, jeszcze działają mechanizmy samoobronne przed dominacją korporacji.

Specyfika naszych czasów wykreowała szereg wizji, mglistych projektów organizacji świata, rzekomo dla osiągnięcia lepszej jakości życia mieszkańców globu. W dyskursie traktowanym jako naukowy pojawiło się szereg propozycji potencjalnych systemów organizacji czy rządzenia na poziomie światowym, począwszy od bardziej sformalizowanych instytucjonalnie: rząd światowy, globalny parlamentaryzm, globalne państwo, federacja światowa, aż do bardziej płynnych, wręcz mglistych mechanizmów kooperacji międzynarodowej, samoorganizacji, konsensusu. Nietrudno zauważyć, że takie koncepcje nie odnajdują poważnych przesłanek w rzeczywistości, choć często są sygnowane przez autorytety.

Dla wielu globalistów znaczącą inspiracją były postępy integracji wspólnoty europejskiej, a Unia Europejska była i, mimo wszystko, jest traktowana jako wzór unifikacji na wielu polach, od gospodarki poczynając, zaś parlament europejski jako swoisty wzór dla parlamentu światowego. Jeszcze w latach pierwszej dekady naszego wieku z emfazą pisano o Nowej Europie, jej unikalnej architekturze 
instytucjonalnej, jaką należy naśladować, projektując struktury globalne. Popadający w przesadę autor uważał nawet, że Europa może zastąpić Stany Zjednoczone w roli rządu globalnego (Mandelbaum, 2005). Europejczycy, poza zwykle sceptycznymi Anglikami, także dawali się przekonywać argumentom, że sukces supranarodowej Europy zależy od przewagi wspólnych interesów nad narodowymi (Lahav, 2004). Praktyczni Anglicy na długo przed Brexitem antycypowali problemy, jakie mogą wiązać się z destrukcją Europy. W pracy Jaya i Stewarta takie właśnie problemy miały pojawić się w początkach lat 90. (Jay, Stewart, 1987). Inni autorzy, jeszcze w ostatniej dekadzie XX wieku, także nie mieli złudzeń co do istoty integracji europejskiej i dla nich serce monstrum biło w Brukseli (Brooker, Noorth, 1996).

Jak ze sporą dozą sarkazmu zauważył jeden z autorów, im bardziej Unia, ten zaczątek unifikacji globalnej, chce ujednolicić swoje normy, tym bardziej kultury narodowe i regionalne sprzeciwiają się temu, broniąc swojej tożsamości, a takie uwagi zrodziły się tuż po akcesji Polski do Unii (Lewandowski, 2005). Żądza regulacji, charakterystyczna dla tworów Brukseli, powoduje marginalizację małych państw, rodzi frustracje, budzące z kolei radykalne, nieliczące się niekiedy ani ze zdrowym rozsądkiem, ani wewnętrznym prawem działania struktur unijnych. Unijne sztafaże, mówienie o konieczności ściślejszej integracji są kierowane do euroentuzjastow, którym powtarza się, że potrzebujemy więcej tego samego. Dawno już mówiono i pisano o tym, ze Unia musi stać się w pełni podmiotowa, a to oznacza choćby konieczność stworzenia sił szybkiego reagowania i europejskich sił obronnych (Held, 2007). Tymczasem stare projekty Foucheta i Plevena stworzenia Armii Europy okryły się kurzem w przepastnych biurkach urzędników unijnych, a bez parasola NATO Europa jest bezbronna. Niekonsekwencje swoistej konsekwencji unijnych kreatorów widać na każdym kroku, bo i w systemie monetarnym bez wspólnej polityki fiskalnej, w strefie Schengen, która nie chroni zewnętrznych granic, w ogromie działań pozorowanych, będących konsekwencją myślenia magicznego. Takie inspiracje raczej nie są uczące, ale nie przeszkadzają globalistom idealizującym „projekt Europa”.

Wszystkie takie braki działań przykrywa się wzmożonymi kontrolami nad miarę rozbudowanego aparatu biurokratycznego, a nie wspominamy tu o słabym umocowaniu struktur unijnych w procedurach demokratycznych. Apologeci Unii marzą o tym, by Europa stała się imperium, by jak wszystkie uprzednie imperia stała się asymetrycznym porządkiem panowania - twierdzili przeciwnicy Europy narodów, acz trudno zrozumieć, co mieli na myśli (Beck, Grande, 2009). Po Maastricht pisano o „trzynastym państwie 13 narodów”, jakim miała 
być Europa i teraz możemy powiedzieć, iż były to tylko marzenia (Kasstoryano, 2007). W drugiej dekadzie naszego wieku spotykamy coraz więcej głosów wieszczących rychłą śmierć „projektu Europa”, co powinno być jakąś przesłanką dla globalistów. Tu złudzeń nie mają przede wszystkim Anglicy, powiadający jak D. Murray, że część fundamentów kruszy się, że jej mieszkańcy nienawidzą własnych wartości, że „drzewo Europy ostatecznie uschło. Europa nie ma zbyt wielkiej ochoty się rozmnażać, walczyć o siebie ani nawet stawiać na swoim w sporach $z$ innymi. Ludzie władzy sprawiają wrażenie przekonanych, że nie miałoby większego znaczenia, gdyby mieszkańcy i kultura Europy zostały stracone dla świata" (2017). Taka Europa już nie może być wzorem dla globalistów mityzujących multikulturalizm, otwartość granic i propozycje A. Giddensa z jego Trzeciej Drogi są już bardzo nieaktualne, podobnie jak liczące niewiele ponad dziesięć lat sugestie globalisty (Laszlo, 2006).

Nie tylko zwolennicy Unii wieścili rychły zmierzch narodów w czasie żywiołowego rozszerzania. Bezrefleksyjnie powtarzano, jak A. Smith, że idea narodowa jest zbiorem prymitywnych sentymentów rozwijanych przez natrętną retorykę (2007). Narody bronią się skutecznie i wciąż koncentrują dynamikę społeczną, organizują sposoby myślenia o przeszłości i przyszłości, są formą tworzenia wszystkich rodzajów wspólnot i taką pozostaną przez czas jakiś, choć warte uwagi są sugestie o upadku instytucji państwa (Attali, 2008). Zauważamy symptomy takiego słabnięcia nie tylko w rosnącej liczbie państw upadłych i upadających, i jak dotąd, nie potrafimy sobie radzić ani z analizami, ani diagnozami: siły sprawcze tych procesów pozostają ukryte. Za to coraz wyrazistsze stają się konsekwencje słabnięcia państw, a taką konsekwencją jest wzrost przestępczości wiązany z urzędnikami i skorumpowanymi służbami państw (Glenny, 2008). Inny autor dopełniał takie uwagi sugestią, że już mamy do czynienia z międzynarodową Pax Mafiosa i nie doceniamy jej znaczenia, wpływu na struktury państwowe (Godson, Wiliams, 2005). Być może słabości tych państw i rosnąca przestępczość to znaczące przesłanki inspirujące poszukiwanie nowych form zarządzania, także w skali globalnej. Zainteresowane tym są przede wszystkim korporacje, dla których takie formy działań przestępczych są tylko przeszkodą w interesach. Działając legalnie, wolą wykorzystywać dla swoich celów struktury państw, co jest rozwiązaniem tańszym, choć coraz częściej sięgają po pomoc prywatnych agencji, coraz bardziej przypominających prywatne armie.

Nietrudno zauważyć, że także w państwach wysoko uprzemysłowionych formy władzy posiadają wiele deficytów, a między nimi brak demokratycznej kontroli, społecznej partycypacji, niekompetencji polityków. W takich warun- 
kach rekonfiguracja obecnych modeli państwowych wydaje się koniecznością, gdyż problemy, z jakimi się stykają, stają się zbyt złożone. Poszukiwanie nowych form władztwa inspiruje teoretyków odnajdujących remedia na niewydolność państw w „rządzie sieciowym”, skupiającym organizacje i grupy interesu (Duffield, 2007) . Koncepcja równie mglista jak dziesiątki innych, bowiem zakłada się, że to państwo dokonuje koordynacji prac podmiotów konstytuujących sieci władzy poprzez zlecanie im poszczególnych zadań, one zaś mają ad hoc konfrontować swe pomysły $\mathrm{z}$ wieloma innymi. Można z sarkazmem zauważyć, że nieudolne państwo będzie starało się zapanować nad chaosem spowodowanym przez pertraktacje między wszystkimi uczestnikami procesu. W dodatku owe podmioty nie są dookreślone, nie wiadomo, jak mają wyglądać zależności między nimi, sama hierarchizacja.

Wizjonerzy najbardziej wizyjni zwykli traktować swoje uwagi jak imperatywy ludzi iluminowanych, czasami nie biorąc odpowiedzialności za słowo, jak w przypadku S. Benhabib, piszącej iż: „Nowa globalna cywilizacja musi zrozumieć siebie jako multikulturalną i multipolarną" (2002). Uważają, że społeczeństwa dojrzeją do zrozumienia konieczności globalnej unifikacji, pojawi się wspólnota celów i wejdą na nowy poziom wspólnoty globalnej i wtedy ziszczą się marzenia antyglobalistów oraz przedstawicieli innych, oddolnych ruchów społecznych o pracy na rzecz szczęścia ludzkości. Inaczej myślą trzeźwiej patrzący na takie koncepcje i uważają, iż zarządzanie globalne jest i będzie zdominowane przez wąskie grupki menadżerów powiązanych mocnymi więzami z korporacjami nadnarodowymi (Nanz, Steffek, 2007).

Pożądany i zapowiadany przez wielu multikulturaklizm bywa tu rozumiany jako generowane przez globalizację kulturową zjawiska jej homogenizacji, kreolizacji itp., choć na pierwszy rzut oka widać, iż ten multikulturalizm w skali globalnej to zdecydowana amerykanizacja. Patrząc na teorię i praktykę tego „multikulti”, można dostrzec, iż westernizacja, makdonaldyzacja, konsumeryzm często prowadzą do niszczenia lokalnych kultur odpowiedzialnych za podtrzymywanie spójności, tożsamości. Nie chce się zauważać, że niszczenie wartości duchowych czy kulturowych oddziałuje z o wiele większa siłą niż materialnych i reakcją na to bywa nawrót do wartości mocowanych w religii, czego świadkami jesteśmy dziś. Jednak błędem najpoważniejszym teoretyków szczęśliwego, nowego świata jest postrzeganie obywateli drugiego i trzeciego świata $\mathrm{z}$ naszych punktów widzenia i tu mamy do czynienia nie ze zderzeniem, a konfrontacją cywilizacji.

Raczej niewyobrażalne są konflikty symetryczne, ale antycypowany od lat konflikt między Południem a Północą to napływ milionów imigrantów, wobec 
których bogaci nie potrafili zająć stanowiska wtedy, kiedy można było pomagać w ich miejscach zamieszkania. A wtedy już mówiono, że wszystkie problemy są globalne. Nędza Trzeciego Świata niemającego wiele do zaoferowania globalnej gospodarce już rodzi poważne destabilizatory ładu w skali lokalnej i globalnej, i te problemy będą się eskalować. Konflikty o niskiej intensywności (semiwojny) są codziennością w Afryce i Azji, i o takich nie chce się pamiętać. Ci, którzy dostrzegają wagę takich przesłanek, tworzą scenariusze zniszczenia dotychczasowego ładu i globalnego totalitaryzmu. Drudzy natomiast tworzą wizje ekonomiczno-politycznego totalitaryzmu, do którego może doprowadzić wielki kryzys ekonomiczny, globalna wojna albo reakcja potęg na nieudaną rebelię państw trzecich. Tu spotykamy jakby dopełnienie wizji Orwella i innych twórców dystopii, a są to: kontrola siły roboczej przez korporacje, represje policyjne, eugenika, regulowana przez państwo eutanazja, a nawet eksterminacja całych grup społecznych (Goldfrank, 2007).

Takie sugestie jak powyższe możemy traktować jako wyraz bezradności wobec problemów, które dziś wydają się nierozwiązywalne. Rodzą setki pytań, a nie mogą satysfakcjonować odpowiedzi podobne do poniższej: „Budowa nowego świata może stać się ciałem dzięki nowej Deklaracji Niepodległości dla całego świata" (Plattner, 2008). Tu także przejawia się naiwna wiara w sprawczą moc słowa i brak pytań oczywistych, choćby o to, jak wyrównać poziomy życia bogatych i biednych, jak likwidować „lukę ludzką”, regulować przepływy imigracyjne. Za to mamy jakieś kontaminacje koncepcji filozoficznych, socjologicznych i jakieś formy teologii politycznej, raczej nie w rozumieniu C. Schmitta. S. Ramphal powiadał górnie, że ewoluowaliśmy od rodziny przez plemię do świata narodów, a teraz odchodzimy w erę wspólnoty wszystkich ludzi świata. On, jak i wielu innych wizjonerów, rzucał swe wizje poza horyzont zdarzeń, wiedząc, że nie ziszczą się za życia współczesnych. Wiele tu podobieństw z budowniczymi komunizmu, powiadającymi, że buduje się podwaliny pod promienną przyszłość wnuków naszych wnuków.

Państwo globalne ma być szczególnego rodzaju remedium na wszystkie bolączki naszego czasu. W świecie globalnych rynków - utrzymywał M. Slaughter - globalnej informacji, możliwości przekraczania granic, broni masowego rażenia, zagrożeń ekologicznych rządzenie musi być globalne (Slaughter, 2005). I tu pojawiają się mgliste projekty rządu światowego, firmowane przez postaci mające status autorytetów, różniące się stosunkiem do form państwa globalnego, roli narodów. Dla większości trzeźwo patrzących teoretyków państwa narodowe powinny jednak przetrwać. M. Walzer, pozostający na takim stanowisku, uważał, 
że potencjał władczy zależałby od praw dobrowolnie scedowanych przez państwa członkowskie na rzecz federacji. Taki podmiot globalny miałby na początku charakter oligarchiczny bądź też byłby kontaminowany z ograniczoną demokracją. Wewnątrz istniałby porządek konstytucyjny, oparty na konstytucji globalnej, podział funkcji pełnionych na poszczególnych szczeblach władzy, a obywatelom przysługiwałyby instancje odwoławcze gwarantujące ich prawa (2006).

Niektórzy uważają, że państwa narodowe nie mogą przeciwstawić się siłom globalizacji w sytuacji, gdy ich naturalne fundamenty zaczynają erodować i skończyła się kulturowa hegemonia państw narodowych (Stevenson, 2003). Twórcy takich koncepcji zwykle nie precyzują istoty „sił globalizacji”: te jakby były niezależne, „obiektywne” jak sama globalizacja, i nie przyjmują do wiadomości, że w świecie człowieka nie ma zjawisk obiektywnych, one wszystkie zależą od niego, w mniejszym czy większym stopniu.

Zastanawiając się nad problemem globalnego władztwa, A. Etzioni sugeruje, że już dziś mamy do czynienia z formowaniem się jego zaczynu i ma on charakter przypominający imperium, w którym grupa najpotężniejszych państw z USA na czele wywiera naciski polityczne na resztę państw. Taka konstrukcja oparta jest na hipotezie, że powstawanie światowej władzy będzie przypominało powstawanie państw narodowych, gdyż w obu przypadkach bezpieczeństwo determinowało nadrzędne cele podejmowanych działań. Wedle Etzioniego konstytuowanie się rządu globalnego będzie przejawiać się w formach: 1) światowego departamentu do zwalczania terroryzmu, 2) sfery dotyczącej ograniczenia rozprzestrzeniania się broni nuklearnej, 3) kwestii mających na celu prewencję humanitarną (pandemia, ludobójstwo) (2004).

Global government byłby oczywiście władzą wykonawczą, gdyż kwestionowanie demokratyzmu, czyli trójpodziału władz, byłoby traktowane jak herezja. Dla kilku autorów parlament światowy winien przyjąć postać podobną do europejskiego i możemy wątpić, czy sugerujący takie rozwiązania mają wystarczające ilości dobrych przesłanek.. Wedle innego teoretyka członkowie parlamentu globalnego nie byliby wiązani wytycznymi swoich państw macierzystych, ale głosowaliby wedle interesów grup, jakie reprezentują. Nadto wyłonienie globalnej reprezentacji mogłoby dojść do skutku poprzez koalicję składającą się z komórek społeczeństwa obywatelskiego, przedstawicieli biznesu i mediów, którzy dokonaliby konfirmacji traktatu mającego reprezentować „globalną opinię publiczną" (Zweifel, s. 178). Komentarz do tak ekwilibrystycznych łamańców może sprawiać wiele kłopotu, nie wspominając o podstawowych pytaniach, jakich nie zadano. 
Takich pytań są setki i pośród nich pojawiają się te, które traktują o charakterze wspólnoty globalnej. Pojawiają się głosy mówiące o istnieniu potrzeby tworzenia idei i instytucji umożliwiających ludziom naszego czasu przygotowanie się do egzystencji na poziomie globalnego plemienia, jakim się rzekomo już stali (Appiah, 2006). Wielu uczonych uważa kulturę kosmopolityczną za naturalną konsekwencję postępu, za produkt kultury postmodernistycznej (Beck, 2007). Optymistycznie nastawieni zwolennicy kosmopolityzmu sugerują, że współczesnym społeczeństwom brak mitologii planetarnej, a taką odnaleźć można w archetypach stanów idealnych - rajów utraconych (Eliade, 2007). Tenże kosmopolityzm w jego radykalnej postaci to żądanie równości dla wszystkich mieszkańców globu, poczynając od politycznej, a kończąc na ekonomicznej (Cabrera, 2004). Zwolennicy tak skrajnego egalitaryzmu stanowią jednak mniejszość, bowiem bardziej trzymający się ziemi zwolennicy globalizmu są skłonni uważać, że o wiele mocniejszym spoiwem ewentualnej wspólnoty może się okazać strach, jak dla U. Becka, twórcy koncepcji społeczeństwa ryzyka. Jego społeczeństwo konstytuuje wspólnotę strachu, a solidarność wynika ze zbiorowego lęku. Globalna świadomość ryzyka, jaka nie może być zanegowana ani eksternalizowana, nosić może w sobie potencjał dla wykreowania globalnej społeczności, zniesienia podziałów wygenerowanych przez państwa narodowe oraz stare tradycje (Beck, 2005).

$Z$ jednej strony są to idealizowane nad miarę wizje harmonii i ładu, jak powyżej, a z drugiej dystopijne, jakby inspirowane literaturą science fiction, bo tu filiacje są uderzające, choć te drugie są ubierane w inne szaty, ale podobieństwo tych koncepcji do utworów N. Shute’a, A. Piersa, A. Carter i dziesiątków innych pisarzy są uderzające. Uważa się, że niemożliwość kreacji regulatorów w skali globalnej może doprowadzić do powstawania semianarchicznych „nowych wieków ciemnych”, do „nowego średniowiecza”, w którym pojawią się konflikty między państwami a aktorami niepaństwowymi, granice staną się płynne, zmienią się tożsamości i lojalności, wzrosną nierówności społeczne, pojawią się strefy zakazane (No-go), a nowoczesne uzbrojenie trafi w ręce różnych podmiotów zagrażających ładowi międzynarodowemu.

Nie wyklucza się także wojen, a zwykle antycypuje się ograniczone wojny o surowce, choć niektórzy autorzy przepowiadają nadejście wojen klimatycznych. Zmiany klimatu mogą spowodować masowe migracje setek milionów ludzi i nikt nie będzie w stanie zatrzymać tej fali, a to zdaje się potwierdzać napływ imigrantów w naszym czasie. W warunkach totalnego zagrożenia mogą się pojawiać imperia $\mathrm{z}$ ich nieubłaganą logiką, jaką $\mathrm{w}$ opowiadaniu Logic of Empire 
zbliżał się dawno temu znakomity pisarz R. Heinlein. Niektórzy teoretycy poszukują przesłanek do wniosku, że autorytarne państwo może okazać się jedyną alternatywą dla dotychczasowego systemu podupadających i popadających w konflikty wojenne między sobą. Uważają, że taki supranarodowy totalitaryzm może powstać jako efekt politycznego chaosu, jaki może pojawić się wskutek proliferacji broni masowego rażenia w dążeniu do "utopii tyranii dobrobytu”, co czytelnikom tego autora znowu może sprawić kłopoty interpretacyjne (Carneiro, 2004).

Jak często bywa, spojrzenie zdroworozsądkowe jest bardziej przekonujące i nie spekulując na raczej wątłych podstawach, jakimi są ledwo zauważalne trendy, powinniśmy zakładać, że jeśli powstanie system globalny, to nie będzie on przypominał żadnego ze znanych. Mając na uwadze złożoność współczesnego świata, możemy sugerować, że dotychczasowe, najczęściej spotykane wizje i koncepcje globalnego władztwa, w tym parlamentów światowych, są najczęściej symplifikowanymi ekstrapolacjami form już znanych. Przy tym zwykle nie bierze się pod uwagę problemów skali, jakie wyniknęłyby przy próbach transpozycji form demokracji na poziom globalny. Widać, że uproszczeniom podlegają „modne” wśród teoretyków koncepcje global governance, zakładające możliwość zaistnienia zgodnej współpracy między różnymi podmiotami, oddolnej aktywizacji, spontanicznego uświadamiania sobie wspólnych celów jako form samoorganizacji oraz realizacji form władczych. Można uznać, że inspiracją dla takich postulatów amorficznych form porządku światowego może być to, co A. Slaughter określił mianem paradoksu globalizacji, gdzie w miarę postępu procesów globalizacji istnieje wzmożona potrzeba na rządzenie w skali globalnej i regionalnej, wobec której istnieje mocny sprzeciw, ponieważ narody i państwa nie akceptują centralizacji podejmowanych decyzji oraz przymusowej władzy, a obywatele widzą takie formy rządu jako zagrożenie $(2005$, s. 8).

Kreatorzy państwa globalnego nie chcą zauważać, że stworzenie nowej jakości będzie wymagało niszczenia tego, co istnieje dziś, czyli narodów jako wspólnot, kultur, zmuszania do wyzbywania się niechęci do innych. Może zastanawiać brak pytań oczywistych o to choćby, kto i jakimi sposobami ma tego dokonać? Jak wyglądają determinanty ekonomiczne i polityczne? Jak tworzyć nową socjoi psychosferę? Czy tak, jak się to czyni dziś, choć w delikatnych formach zmuszania do poprawności politycznej, choć takie określenie to zwykły oksymoron? Nie przeszkadza im to, że są tak irracjonalni, dla wielu z nich konieczność tworzenia tego państwa to coś „obiektywnego” i zwykle nie przyjmują do wiadomości tego, iż taki obiektywizm nie istnieje w światach człowieka. Ci, którzy kwestionują ich 
projekty, są zwykłymi rasistami i ksenofobami i nie warto z nimi dyskutować. W jakiejś mierze wizjonerami powoduje to pragnienie, o jakim pisał swego czasu K. Popper, czyli niecierpliwe pragnienie polepszenia losu bliźnich (2007), a jakiego zbyt często nie dostrzegają badacze. Właściwie ono powodowało, gdyż dysputy wokół idei państwa globalnego przycichły na czas jakiś, co może mieć związek z kłopotami z realizacją projektu europejskiego, ale także z zauważalną w naszym czasie atrofią i form, i treści demokracji.

Próbując zreasumować powyższą prezentację, zastanawiać może, że większość tych wizji powstaje w środowiskach uniwersytetów cieszących się światową renomą i są subsydiowane przez fundacje oskarżane często o inspirowanie projektów bliskich tym „bredniom”, o jakich pisał swego czasu F. Wheen (2005). „Ideologie” globalizmu czy kosmopolityzmu, jeśli można je tak nazywać, są dość mocno rytualizowane, ale po to, by zajęły odpowiednie miejsce w wyobrażeniach zbiorowych, potrzebna jest jeszcze społeczna akceptacja, a takiej nie ma. Nie ma także wyraźnego odzewu polityków, ale ci są związani z państwami narodowymi i narodami jako wspólnotami i ten brak zainteresowania jest zrozumiały. Problematyczne jest nazywanie ich naukowymi, one są bliższe wierze immanentnej, będąc jakby częścią tej religii postępu, o której pisali Ch. Dawson i D.J. Boorstin. Dostrzec tu można eschatologiczne tęsknoty, jakie towarzyszyły politologom ostatniej dekady ubiegłego wieku, naiwne pragnienie celebrowania „końca przyszłości” tu i teraz, ale od tamtego czasu owe tęsknoty zderzają się z twardymi realiami polityki.

\section{BIBLIOGRAFIA:}

Acemioglu, D. (2014). Świat jaki odziedziczą nasze wnuki. W: Ignatio Palacios Huerta (red.). Gospodarka za 100 lat. Warszawa: Kurhaus.

Ambrose, S.E., Brinkley, D.G. (1997). The Rise to Globalism. New York: Penguin.

Appiah, K. (2006). Cosmopolitanism. New York: Norton.

Attali, J. (2008). Krótka historia przyszłości. Warszawa: Prószyński i S-ka.

Beck, U. (2005). Power in the Global Age. Cambridge: Polity Press.

Beck, U. (2007). Cosmopolitan Vision. Cambridge: Cambridge Polity Press.

Beck, U., Grande, E. (2009). Europa kosmopolityczna. Społeczeństwo i polityka drugiej nowoczesności. Warszawa: Scholar..

Benhabib, S. (2002). The Claims of Culture. Princeton: Princeton University Press.

Besancon, A. (2000). Przekleństwo wieku. Warszawa: Prószyński i S-ka.

Bloom, A. (1997). Zamknięty umyst. Poznań: Wydawnictwo Zysk i S-ka.

Brooker, Ch., North, R. (1996). The Castle of Lies. Why Britain must get out of Europe. London: Duckworth. 
Cabrera, L. (2004). Political Theory of Political Justice. London: Routlege.

Carneirio, R.L. (2004). The Political Unification: Whether, When and How - Some Speculations. London, Sage Publications.

Duffield, M. (2007). Global Governance and a New Wars. London: ZED Books.

Eliade, M. (2007). Obrazy i symbole. Warszawa: Aletheia.

Etzioni, A. (2004). From Empire to Community. New York: Pallgrave Macmillan.

Falk, P. (1975). A Study of Future Worlds. Amsterdam: Free Press.

Glenny, M. (2008). Mc Mafia. New York: Columbia University Press.

Glaasbek, H. (2002). Wealth by Stealth. Corporate Crime, Coerporate Law and the Perversion of Democracy. New York: Kindle Books.

Godson, R., Wiliams, P. (2005). Strengthening Corporation against Transnational Crime. W: Godson R. (ed.), Combating Transnational Crime concepts. London: Faber.

Goldfrank, W.L. (2007). Beyond Cycles of Hegemony. New York: Columbia University Press.

Gordon, L.Jr. N. (1970). Woodrow Wilson and World Politics. London: Galaxy Books. Gray, J. (2001). Po liberalizmie. Warszawa: Wydawnictwo Aletheia.

Gray, J. (2009). Czarna msza. Apokaliptyczna religia i śmierć utopii. Kraków: Wydawnictwo Znak.

Held, D. (2007). Global Governance. Cambridge: Cambridge University Press.

Jay, P., Stewart, M. (1987). Apocalypse 2000. Economic Breakdown and Suicide of Democracy. London: Sage.

Kastoryano, R. (2007), Transnational Nationalism. W: Benhabib S. (ed.), Identities, Affiliations and Allegiances. Cambridge: Cambridge University Press.

Kennedy, D.M. (1982). Over here. The First World War and American Society. London: Oxford University Press.

King, A., Schneider, B. (1992). Pierwsza rewolucja globalna. Jak przetrwać? Warszawa: Państwowe Wydawnictwo Naukowe.

Korten, D. (2001). When Corporations Rule the World. London: Oxford University Press.

Korten, D. (2006). The Great Turning. From Empire to Community. San Francisco: San Francisco University Press.

Kothari, R. (1978). Footsteps into the Future. Stockholm: Free Press.

Lahav, G. (2004). Immigration and Politics in the New Europe. Cambridge: Cambridge University Press.

Lakoff, G. (2017). Moralna polityka. Jak myśla liberałowie i konserwatyści. Warszawa: Wydawnictwo Aletheia.

Laszlo, E. (2006). The Chaos Point. The World of Crusaders. Charlottesville: Hampton Road.

Lewandowski, E. (2005). Pejzaż etnicznej Europy. Warszawa: Muza.

Mandelbaum, M. (2005). The Case of Goliath. New York: Yale University Press.

Murray, D. (2017). Przedziwna śmierć Europy. Poznań: Zysk i S-ka.

Nanz, P., Steffek, J. (2007). Global Governance and the Public Sphere. W: Held D., Koenig M. (red.). Global Governance and Public Accountability. Oxford: Oxford University Press. 
Plattner, M.A. (2008). Democrracy without Borders? Global Challenges to Liberal Democracy. New York: Kindle Edition.

Popper, K. (2007). Społeczeństwo otwarte i jego wrogowie, Warszawa, Państwowe Wydawnictwo Naukowe.

Rothkopf, D. (2008). Superclass. Washington: Wyd. Farrar, Strauss.

Slaughter, A.M. (2005). A New World Order. Princeton: University Press.

Smith, A.D. (2007). Nacjonalizm. Warszawa: Sic.

Sobel, R. (1993). The Age of Giant Corporations. London: Grenwood Press.

Stevenson, N. (2003). Cultural Citizenship. Berkshire: South England University Press.

Szachnazarow, G. (1978). Fiasko futurologii. Moskwa: Izdatielstwo politiczieskoj litiratury.

Świętosławski, Z. (1854). Ustawy Kościoła Powszechnego. W: Lud Polski na emigracji. Jersey.

Therborn, G. (1998). Drogi do nowoczesnej Europy. Kraków: Wydawnictwo Znak.

Thurow, L. (1999). Przyszłość kapitalizmu. Jak dzisiejsze siły ekonomiczne kształtują świat jutra. Wrocław: Wydawnictwo Dolnośląskie.

Voegelin, E. (1992). Nowa nauka polityki. Warszawa: Wydawnictwo Aletheia.

Wallerstein, I. (2006). Utopistic. W: Godwin B. (red.). The Philosophy of Utopia. London: Routlege.

Walzer, M. (2006). Spór o wojnę. Warszawa: Muza.

Wheen, F. (2005). Jak brednie podbily świat. Warszawa: Muza.

Zacher, L. (2006). Gra o przyszłe światy. Warszawa: Wydawnictwo Akademii im. L. Koźmińskiego.

Zweifel, T. (2006). International Organization and Democracy. London: Lynne Rienner Publisher. 